\title{
FEIRA AGROECOLÓGICA DE FRANCISCO BELTRÃO (PARANÁ): UM PROJETO DE PARTICIPAÇÃO SOB O ENFOQUE DA PSICOLOGIA SOCIAL COMUNITÁRIA NA PERSPECTIVA LATINO-AMERICANA?
}

\author{
Francisco Beltrão's (Paraná) agroecological fair: a participation project under the focus \\ of the Community Social Psychology in the Latin American perspective?
}

Juliane Sachser Angnes*

Elisa Yoshie Ichikawa**

\section{RESUMO}

Este artigo tem como objetivo compreender a participação comunitária dos agricultores/feirantes no projeto intervencionista denominado "Feira Agroecológica" em Francisco Beltrão/PR, tendo como base os conceitos pregados pela Psicologia Social Comunitária na perspectiva Latino-americana (PSCLA). Assim, adotou-se uma postura metodológica direcionada para a pesquisa-intervenção-reflexiva por meio da inserção no cotidiano dos agricultores/feirantes em uma posição denominada de interação-dialógica. Neste sentido, se elegeu trabalhar com fontes orais e escritas enfocando a posição discursiva do sujeito por meio de sua participação psicossocial versus discursos legitimados pela história oficial. Os resultados apontaram que a "Feira Agroecológica" é considerada, pelo discurso oficial, como uma proposta de inclusão social, de resistência ao agronegócio, mas o que se presenciou foi um projeto estruturado a partir da ótica do agente externo.

Palavras-chave: Participação Comunitária. Psicologia Social Comunitária Latino-americana. Feiras.

\begin{abstract}
The aim of this research was to understand the community participation of farmers/stallholders in the interventionist project called "Agroecological Fair" in Francisco Beltrão/PR, based on the concepts that underlie the Community Social Psychology in the Latin American perspective (PSCLA). Thus, the methodological approach adopted was a reflexive methodology of intervention, through participation in the daily life of the farmers/stallholders in a position denominated dialogical interaction. In this sense, we chose to work with oral and written sources focusing on the discursive position of the subject by means of his psychosocial participation versus discourses legitimized by official history. The results pointed out that the "Agroecological Fair" is considered, by the official discourse, as a proposal of social inclusion, of resistance to agribusiness. However, what was witnessed was a project structured from the perspective of the external agent.
\end{abstract}

Keywords: Community Participation. Latin American Social Community Psychology. Fairs.

\footnotetext{
* Doutora em Educação pela Universidade Federal do Paraná (UFPR). Professora do Programa de Pós-graduação em Administração da Universidade Estadual do Centro-Oeste do Paraná (Unicentro) - Curitiba (PR), Brasil. E-mail: julianeangnes@gmail.com. ORCID: 0000-0002-4887-7042

** Doutora em Engenharia de Produção pela Universidade Federal de Santa Catarina (UFSC). Professora do Programa de Pós-graduação em Administração da Universidade Estadual de Maringá (UEM) - Maringá (PR), Brasil. E-mail: eyichikawa@uem.br. ORCID: 0000-0001-7096-7653
} 


\section{INTRODUÇÃO}

E ste artigo tem como objetivo compreender a participação comunitária dos agricultores/ feirantes no projeto intervencionista denominado "Feira Agroecológica" em Francisco Beltrão/PR, tendo como base os conceitos propostos pela Psicologia Social Comunitária (PSC) na perspectiva latino-americana. Trata-se de uma pesquisa realizada na linha de Estudos Organizacionais que questiona o referencial dogmático constituído majoritariamente por teorias anglo-saxãs na produção e distribuição dos conhecimentos.

Nesta linha de raciocínio, destacam-se as discussões realizadas por Alcadipani e Rosa (2010), Faria (2014), Barros e Carrieri (2015), entre outros, que salientam a necessidade dos pesquisadores latino-americanos "descolonizarem seu olhar" e começarem a "[...] abrir espaço para utilizarem diferentes epistemologias para compreender o social, 0 cultural e o histórico, de maneira a estabelecer uma relação dialógica com outros discursos nas organizações" (BARROS; CARRIERI, 2015, p. 2).

Para tanto, os resultados da pesquisa trazem à tona as vozes do silêncio, do outro, daquele que não é capaz de produzir saberes legitimáveis de acordo com as teorias dos Estudos Organizacionais dominantes. Em outras palavras, a investigação (pesquisa) e a intervenção (ação) partem do enfoque que discute a realidade da organização por meio das interfaces psicológico-sociais que não compactuam com a epistemologia anglo-saxã dominante nos Estudos Organizacionais.

Neste sentido, escolha do lócus de pesquisa deu-se pelo fato dessa Feira, proveniente do projeto de uma Organização Não-Governamental (a Associação de Estudos, Orientação e Assistência Técnica - Assesoar) ${ }^{1}$ ser uma das poucas, no estado do Paraná, a ter sua origem centrada em políticas públicas na vertente ecológica camponesa ${ }^{2}$ pautada na Teologia da Libertação, o que teria, pelo menos no discurso, uma aproximação muito grande com a Psicologia Social Comunitária (PSC) na perspectiva latino-americana, base para a análise. Explicando de forma mais detalhada: a Assesoar tem como diretriz central ações centradas na Teologia da Libertação que é uma das bases analíticas para a Psicologia Social Comunitária (PSC) na perspectiva latino-americana.

Desta forma estudar a Feira Agroecológica, tratada pela história oficial da ONG como sendo um dos resultados positivos de um projeto de caráter intervencionista proposto no distrito de Jacutinga ${ }^{3}$ na década de 1990, traz à tona compreender se esta intervenção

1. O Sudoeste paranaense, mesorregião onde se situa o município de Francisco Beltrão/PR, é composto por 37 municípios (conforme regionalização do IBGE), abrangendo uma área de fronteira à Oeste com a República Argentina e ao Sul com o estado de Santa Catarina: caracteriza-se por ser a última área de expansão da fronteira agrícola do estado do Paraná (MORO, 2000).

2. A concepção do projeto ecológico camponês é vinculada à corrente de produção orgânica direcionada para a agroecologia. Ou seja, esta corrente concebe a produção sem o uso de insumos químicos, agrotóxicos, fertilizantes, organismos geneticamente modificados, entre outros (MEDAETS; FONSECA, 2005).

3. Jacutinga é um distrito rural, distante $35 \mathrm{~km}$ da sede do município de Francisco Beltrão. A localidade é composta por uma pequena vila a qual se concentram, além dos serviços públicos e religiosos, um pequeno comércio e um agrupamento de residências. A população de Jacutinga, na época do Projeto Vida na Roça, era constituída por 133 famílias de pequenos agricultores. 
psicossocial permite captar os diferentes processos de participação entre os sujeitos pesquisados na organização, bem como os impactos que esta relação produz no cotidiano dos Estudos Organizacionais sob o enfoque comunitário.

Conforme dados disponibilizados no website e em cartilhas da ONG, a Feira surgiu "[...] do movimento de reivindicação proposto por esta nos anos 1990, em contraposição à Revolução Verde, que contribuiu junto às centrais de associações, grupos de agricultores, visando o estudo e o debate para o fortalecimento a respeito da matriz tecnológica e na organização da produção" (ASSESOAR, 2015, p. 12).

Neste sentido, a proposta inicial para a criação da Feira Agroecológica surgiu em 1996 a partir do Projeto Vida na Roça (PVR), como resultado:

Da participação dos agricultores familiares nas Escolas Comunitárias de Agricultores (ECAs), processo educativo não-formal realizado em regime de alternância - espaço de articulação e de formação de agricultores e representantes de organizações do campo - no qual se debatiam questões locais/ regionais do desenvolvimento rural (leituras de conjuntura, dimensão produtiva, comercialização e organização social), estimulava-se a cooperação (o diálogo de saberes, a partilha de sementes) e estudava-se alternativas coletivas aos problemas identificados por meio de metodologias participativas e multidimensionais (ASSESOAR, 2015, p. 17).

Esta proposição ou "visão de mundo" do Projeto Vida na Roça foi retirada do website e traz consigo os padrões da "história oficial"4. Todavia, ao ingressar em campo de pesquisa percebeu-se que esta visão de mundo sobre as "metodologias participativas e multidimensionais" não ocorreram de forma tão linear e homogênea, mas repletas de conflitos entre agentes externos e internos.

Foi neste momento que se optou pela inserção da história oral como foco analítico do projeto Vida na Roça. Até mesmo porque não se pode compreender a história atual sem conhecer o passado. É preciso confrontar-se com o passado e desvendar a mentira institucionalizada que, ao longo de décadas, vêm oprimindo e alienando os povos latino-americanos (MARTIN-BARÓ, 1998).

Mas, será que esse processo, principalmente o da criação/existência da Feira, ocorreu da forma como a ONG apresenta? Conforme Freitas (2009; 2015a), os projetos realmente intervencionistas produzem uma intrincada rede de relações que envolvem sujeitos que circulam por diversos espaços socialmente construídos e possuem interesses conflitantes. Todavia, a grande maioria das propostas ou projetos que se "rotulam" intervencionistas com foco comunitário, grosso modo, reduz os sujeitos beneficiados a uma categoria homogênea.

O fato dos últimos 40 anos presenciarem uma grande expansão dos chamados "trabalhos comunitários", pode dar, erroneamente, a ideia de que vários setores e grupos da sociedade estão se organizando, estão participando de processos de reivindicação em torno de suas necessidades primordiais e estão sendo contemplados em seus direitos à vida e à cidadania.

4. Conforme Ichikawa e Santos (2010, p. 182) a história oficial é consagrada por expressar interpretações feitas, quase sempre com o auxílio exclusivo da documentação escrita e oficial. 
Infelizmente, esse movimento de ampliação das propostas, intenções e até mesmo de programas e trabalhos voltados para a maioria da população, não tem significado que a mesma esteja sendo atendida em suas necessidades, e muito menos que estejam sendo implementadas formas de participação comunitária que poderiam contribuir para o desenvolvimento de uma consciência crítica e politizada na própria comunidade (FREITAS, 2002, 2015b; SANDOVAL, 1997; ALMEIDA COSTA, 2011).

Assim, para a Assesoar, propositora do projeto, a Feira Agroecológica é considerada como uma forma de resistência camponesa ao agronegócio e uma forma de comercialização de produtos de forma direta, priorizando metodologias coletivas na dimensão produtiva, tais como hortas mandalas, caldas e insumos orgânicos, resgate e reprodução de sementes crioulas entre outras. Prova disto encontra-se na descrição do projeto no website da ONG.

Entretanto, parte-se do pressuposto epistemológico e metodológico de compreender tal posição de forma dialógica, e, nesta perspectiva, essencial dar voz e ouvidos aos agricultores da comunidade Jacutinga (feirantes e não-feirantes) sobre as relações estabelecidas no decorrer deste processo e os efeitos sociais esperados e produzidos, identificando o tipo de participação que tiveram.

Portanto, a pesquisa realizada apresentou questões indagadoras tais como: houve/ há participação comunitária das famílias de agricultores na proposição e execução da Feira Agroecológica em Francisco Beltrão/PR? O que as práticas comunitárias revelaram/revelam? Trata-se realmente de um projeto de intervenção psicossocial comunitária sedimentada no que propõe a Psicologia Social Comunitária (PSC), na perspectiva latino-americana? Os próximos tópicos tentarão responder a essas indagações.

\section{PSICOLOGIA SOCIAL COMUNITÁRIA: PRINCIPAIS CARACTERISTICAS}

De acordo com Façanha (2006) a Psicologia Social Comunitária (PSC) originou-se a partir da Psicologia Social ${ }^{5}$. Ou seja, com o estabelecimento da Psicologia Social, no início do século XX, tendo como marco inicial os dez volumes "Völkerpsychologie"6 escritos por Wundt (entre 1900 a 1920) no mesmo ambiente em que este realizava experimentos de psicologia no laboratório de Leipzig, na Alemanha, surgiu a divisão da Psicologia em ciência natural e ciência social.

Em complemento, Farr (2004) destaca que tal divisão entre a psicologia como ciência natural e social deu origem a vários modelos distintos de atuação do psicólogo, como por exemplo, na empresa, na clínica, na escola, no hospital e na comunidade. Porém, foi somente em 1950, nos Estados Unidos da América (EUA) que os estudos do "social" (do indivíduo para a sociedade) na psicologia foram resgatados, num contexto histórico pós-Segunda Guerra Mundial. Neste período, passou-se a considerar tarefa psicológica a in-

5. Para uma compreensão mais aprofundada da Psicologia Social Comunitária há necessidade de estudar o percurso histórico da evolução da Psicologia Social. Como este não é o objeto de discussão deste estudo, sugere-se a leitura em Façanha (2006) e Almeida (2012).

6. Expressão alemã que significa Psicologia dos Povos. 
tervenção nas relações humanas dos grupos visando harmonia e produtividade da sociedade e o desenvolvimento econômico (FAÇANHA, 2006).

Em complemento, Almeida (2012) aponta que a visão norte-americana de psicologia social se pautava pelo método experimental, com a valorização do individualismo, do etnocentrismo, do cognitivismo (behaviorismo e psicanálise) e do a-historicismo em busca da integração social e a produtividade econômica, mas não considerava a exclusão social.

Nesta perspectiva americana estabeleceu-se, no mesmo período, uma corrente denominada Psicologia Social Comunitária Norte-Americana (PSCNA) na linha da Saúde Mental. Para o autor, esta defendia a reintegração dos doentes mentais na comunidade e apelava para uma perspectiva preventiva do sofrimento humano e a promoção de uma visão positiva da saúde mental.

Corroborando, Lane e Codo (1994) esclarecem que a PSCNA tratava-se de uma derivação da Psicologia Clínica tendo o conceito de empowerment ${ }^{7}$ como uma de suas diretrizes inovadoras. Entretanto, Campos (1996) afirma que as propostas criadas nesta corrente tinham como objetivo melhorar o tratamento psiquiátrico superando a hospitalização clássica, porém com mudanças mais aparentes do que estruturais.

Em contraponto, Façanha (2006) acrescenta que paralelo ao movimento norte-americano, na Europa, a fenomenologia com Kurt Lewin, buscava uma visão mais holística de homem para a Psicologia, por meio da chamada Teoria de Campo ${ }^{8}$. Por sua vez, em 1960, na França, a psiquiatria começava a ser trabalhada de forma a considerar uma intervenção geograficamente delimitada e, na Itália, em 1961, iniciava o movimento anti-psiquiátrico visando a desospitalização e o tratamento em sociedade dos indivíduos que sofriam de problemas mentais.

Nesse sentido, Arendt (1997) afirma ser a Psicologia Social Comunitária, por um lado, instituída e focada na psiquiatria social e preventiva, à dinâmica e psicoterapia de grupos, práticas "psi" que conceituavam uma origem social a seus objetos de estudo (conforme a PSCNA apregoava), e por outro lado, sedimentada por psicólogos sociais na França e Itália que passaram a colocar em questão a neutralidade dos pesquisadores centrados no modelo empírico-analítico.

Com essa subdivisão deu-se início à denominada "crise" da Psicologia Social. Devido a isso, observa-se que foi sob a influência da filosofia francesa e do movimento institucionalista que as práticas dos psicólogos passaram a ser criticamente avaliadas a partir de referenciais antropológicos, históricos e políticos.

Todavia, Façanha (2006) apresenta que embora as primeiras conceituações e práticas comunitárias em Psicologia tenham sido norte-americanas ou europeias, foi na América Latina que a disciplina propôs contornos característicos específicos, a partir dos anos 1960. Em primeiro lugar, Wiesenfeld e Sánchez (1991) destacam que, na América

7. O conceito de "empoderamento" nesta perspectiva focaliza a percepção individual sem conectá-la a uma visão sócio-política.

8. Segundo Minicucci (2002), essa teoria afirma que o comportamento humano depende das mudanças que ocorrem em seu espaço de vida (campo), que é constituído da pessoa e do meio psicológico e como este meio existe para o indivíduo. 
Latina, houve a preocupação de um grupo de psicólogos que sentiam a necessidade de mudar o foco da Psicologia Social, que à época, imitava predominantemente a abordagem experimentalista norte-americana. Segundo eles:

Não estava se baseando na realidade para a qual ela estava suposta de atuar, mas que o conhecimento que estava sendo importado era, de certa forma, questionável naquele contexto. Assim, a contribuição da psicologia social para a solução de problemas educacionais, de saúde, de moradia, de trabalho, entre outros, especialmente em grupos de baixa renda, passou a ser questionada por acadêmicos e pelos governos (WIESENFELD; SÁNCHEZ, 1991, p. 114).

De acordo com Arendt uma segunda condição para o surgimento da Psicologia Social foi o desenvolvimento de movimentos que teriam se organizado como "[...] resposta à histórica frustração dos cidadãos que sofriam de falta de atenção e interesse da parte de agências governamentais responsáveis pela solução de problemas e de organizações políticas que procuravam representá-los junto aos grupos locais de poder" (ARENDT, 1997, p. 114).

E, por fim, como terceira condição para a emergência dessa nova disciplina, Arendt (1997) ressalta a influência do pensamento de autores como o brasileiro Paulo Freire e o colombiano Orlando Fals Borda, introdutores da metodologia da pesquisa-ação como um procedimento fornecido aos psicólogos sociais para promover a ideia de autogestão nas comunidades.

Cedeño (1999) destaca que além dos autores mencionados acima houve a contribuição ainda do argentino Ezequiel Ander Egg, em relação ao trabalho social, educação e autogestão, do padre jesuíta e psicólogo social Ignácio Martín-Baró, de El Salvador, versando sobre as desigualdades do sistema salvadorenho, a tortura e o trabalho com grupos por uma "psicologia da libertação", Maritza Montero na Venezuela, Alberto Andib Andery, Elizabeth de Melo Bonfim, Silvia Maurer Lane, Maria de Fátima Quintal de Freitas, entre outros, no Brasil.

Porém, sem desconsiderar a contribuição destes vários autores, neste estudo optou-se por discutir os referenciais teóricos de Martín-Baró (1987; 1998), Maritza Montero (1994; 2006; 2008) e Maria de Fátima Quintal de Freitas (2002; 2003; 2005; 2006; $2009 ; 2011$; 2015), sobretudo no que concerne às suas contribuições à sistematização das principais teorias e metodologias que vêm sendo utilizadas ao longo dos últimos quarenta anos em toda a América Latina.

Desta forma, com base nos referenciais teóricos elegidos, tem-se que Psicologia Social Comunitária, na perspectiva latino-americana, também seja uma perspectiva da Psicologia Social que surgiu das práticas na área da saúde, na educação popular e nos movimentos sociais e acadêmicos. Segundo Freitas, no Brasil, nos primeiros anos da década de 1960 "[...] aconteceram tentativas de significativas transformações, como por exemplo, os trabalhos executados no nordeste do país, de educação popular e de adultos, fundamentados na filosofia e no método de Paulo Freire" (FREITAS, 2002, p. 49). 
Neste sentido, Montero (1994) e Freitas (2002) sustentam que ao se adotar o direcionamento de investigação-intervenção pautado na Psicologia Social Comunitária na perspectiva latino-americana deve-se levar em conta alguns aspectos (Quadro 1):

Quadro 1 - Aspectos da Psicologia Social Comunitária (PSC) na perspectiva latino-americana

\begin{tabular}{|l|l|}
\hline Aspectos da PSCLA & Descrição \\
\hline $\begin{array}{l}\text { 1) Referência teórica na qual a prática } \\
\text { define-se no campo de produções da Psicologia } \\
\text { Social crítica e histórica. }\end{array}$ & $\begin{array}{l}\text { Concebe o homem em uma perspectiva socio-históri- } \\
\text { ca dialeticamente construída e em movimento. }\end{array}$ \\
\hline 2) Trabalho de cunho coletivo. & $\begin{array}{l}\text { As especificidades do contexto devem caracterizar-se } \\
\text { por uma perspectiva inter, multi e transdisciplinar. }\end{array}$ \\
\hline $\begin{array}{l}\text { 3) Um estabelecimento de articulações entre } \\
\text { aspectos macroestruturais e microestruturais, } \\
\text { teóricos e práticos. }\end{array}$ & $\begin{array}{l}\text { Considera categorias conceituais como consciência, } \\
\text { identidade, atividade-trabalho, afetividade-emoção, } \\
\text { grupo e poder. }\end{array}$ \\
\hline $\begin{array}{l}\text { 4) Desenvolver uma proposta de pesquisa } \\
\text { participante }\end{array}$ & $\begin{array}{l}\text { Considerar que não basta observar e descrever } \\
\text { a realidade há que intervir para propiciar uma } \\
\text { mudança no tocante à construção da cidadania da } \\
\text { comunidade pesquisada. }\end{array}$ \\
\hline $\begin{array}{l}\text { 5) Realidade social como orientadora funda- } \\
\text { mental dos estudos psicológicos. }\end{array}$ & $\begin{array}{l}\text { Reconhecer o caráter ativo dos seres humanos como } \\
\text { produtores da história. }\end{array}$ \\
\hline $\begin{array}{l}\text { 6) Levar em conta que conflito é parte da ação } \\
\text { humana. }\end{array}$ & $\begin{array}{l}\text { Reconhecer a importância da ideologia como } \\
\text { fenômeno psicológico, além de compreender o } \\
\text { caráter enganoso da percepção (que é mediada pela } \\
\text { linguagem). }\end{array}$ \\
\hline $\begin{array}{l}\text { 7) Incluir estudos sobre a relação entre indiví- } \\
\text { duos e vida cotidiana. }\end{array}$ & $\begin{array}{l}\text { Construir diariamente os sentidos dados ao mundo } \\
\text { e àda e rechaçar a noção linear de progresso } \\
\text { científico. }\end{array}$ \\
\hline
\end{tabular}

Fonte: Elaborado pelas autoras baseado em Montero (1994) e Freitas (2002).

A partir do exposto no Quadro 1, entende-se que a Psicologia Social Comunitária (PSC) na perspectiva latino-americana, distinguiu-se da norte-americana principalmente por seu contexto de desenvolvimento que foi marcado por revoluções e lutas sociais contra sistemas totalitários, sendo uma psicologia voltada ao processo de participação democrática visando à transformação social.

Percorrendo uma trajetória analisada por Freitas (2005), pode-se afirmar que a "psicologia na comunidade" (década de 1960 e 1970) foi assim identificada em momentos que a psicologia vivia uma crise em relação aos modelos importados, distantes da realidade brasileira. A psicologia precisava ser desenvolvida na comunidade e não apenas nos consultórios e nas escolas. O objetivo era "deselitizar" a profissão e deixá-la mais próxima às condições de vida da população.

Freitas (2005) apresenta ainda, que no início dos anos 90, presenciou-se o emprego do termo "psicologia da comunidade". Neste período, foram realizadas atuações de psicólogos em instituições geralmente públicas, como postos de saúde, setores vinculados às instituições penais, órgãos de família. Tais atuações tiveram influência das intervenções psicossociologias, com instrumentais das perspectivas clínicas e educacionais. 
Já no final de década de 90, Freitas diz que os temas no campo de Psicologia Social Comunitária, sobre os quais pesquisadores e profissionais se dedicaram nas últimas décadas, deslocaram-se "[...] de uma perspectiva ampla e abrangente, no que concerne à realidade social, para enfocar e considerar temáticas relativas a situações e contextos particulares e pontuais" (FREITAS, 2006, p. 111).

Em outras palavras, isto quer dizer que na perspectiva latino-americana, nas décadas de 1960 a 1990, discutia-se problemas relativos a setores populares e desprivilegiados. A partir dos anos 2000, esses setores passaram a apresentar um lado mais definido e particular: grupos de mulheres, grupo de homossexuais, grupos nas favelas, nos hospitais, nas igrejas, mulheres negras, menores de rua, grupos políticos, desempregados, indígenas, trabalhadores rurais, outsiders entre outros.

Assim, pensar psicologia nesse enfoque, conforme Scarparo e Guareschi (2007) significa atrelar as práticas cotidianas a prerrogativas da universalidade, da equidade, da integralidade e da participação da comunidade no planejamento, na gestão e na avaliação das ações. Por isso, ao optar por se realizar uma investigação-intervenção nos mais variados contextos, considerando-os como organizações, há possibilidades de eleger-se nas diferentes abordagens da Psicologia Social Comunitária suporte teórico e metodológico para estruturar suas práticas. Em complemento Freitas acrescenta:

\begin{abstract}
Na medida em que se considera a comunidade como uma categoria de análise e intervenção relevante no campo da psicologia, percebe-se que este tem sido um campo que denota diversidades tanto na esfera filosófica quanto na política, tendo em vista os contextos de inserção e os projetos sociais e políticos que legitimam suas práticas (FREITAS, 2009, p. 165).
\end{abstract}

De acordo com a autora, houve o crescimento e participação de profissionais e investigadores das mais diversas áreas de conhecimento nessas problemáticas, porém com as organizações pouco mobilizadas a assumirem propostas de mudanças. Grande parte delas interessa-se na construção de projetos sociais sob a ótica psicossocial, mas sem um incremento da participação social e política das pessoas a quem tais proposições se destinam (FREITAS, 2009).

\title{
A PARTICIPAÇÃO: QUAL SIGNIFICADO PARA PSICOLOGIA SOCIAL COMUNITÁRIA (PSC)?
}

Para Avelar (2007), participação é uma palavra latina, do século XV, oriunda de participatio, participationis, participatum, e significa "tomar parte", compartilhar, associar-se. Na visão de Pizzorno, apud Avelar (2007, p. 45), a participação se refere à ação "[...] que se desenvolve em solidariedade com outros no âmbito do Estado ou de uma classe, com o objetivo de modificar ou conservar a estrutura (e, portanto, os valores) de um sistema de interesses dominantes".

Por sua vez, para Melucci (1996), a participação se refere a toda e qualquer forma de ação coletiva. Este autor propõe que a definição de participação deve levar em conta conteúdos diferentes: a) primeiro que quem participa buscando seus objetivos se identifica com os interesses gerais de um sistema dominante, legitimando-o; e, b) segundo que "[...] 
a participação se dá em um contexto competitivo de interação estratégica e com o objetivo de exercer algum grau de influência na distribuição de poder em benefício de um grupo específico" (MELUCCI, 1996. p. 306).

Nos estudos realizados por Costa (2009), a participação apareceu junto ao Estado de soberania popular, nos séculos XVIII e XIX, durante as revoluções europeias, rompendo a lógica da correspondência entre a posição social e política dos indivíduos. E no Brasil, esta teve maior efervescência durante o século XX (década de 1960 e 1970) quando o país avançou rumo a se tornar uma sociedade urbana.

Por sua vez, o termo participação surgiu no Brasil ao mesmo tempo em que a PSCLA se tornou uma vertente anti-hegemônica ao modelo de psicologia apregoado no modelo norte-americano. Para autores como Sánchez (2000) e Hernández (1997) a participação comunitária abarca um significado de transformação. Não a transformação por meio da luta de classes, mas sim por meio da reflexão e colaboração. Esta colaboração é assim contextualizada por Montero:

Participar é algo maior, todo mundo trabalha unido; colaborar é menor. Significa trabalhar também, mas de forma mais reduzida. Eu posso trabalhar sozinha e colaborar. Quando eu participo, trabalho com outras pessoas. E este trabalho coletivo se transforma e é transformado em uma relação que implica sujeitos, grupos e circunstâncias nas quais se está participando, fator este que implica em decisões, ações, direitos, deveres e conquistas (MONTERO, 2008, p. 227).

A partir da citação, entende-se que na perspectiva comunitária a participação seja: a) ação conjunta e livre de um grupo que compartilha interesses e objetivos; b) contextualização e relação com a história da comunidade e o contexto histórico de suas relações; c) um processo que implica a produção e o intercâmbio de conhecimentos. Dito de outra forma, na concepção proposta por Montero (2008), ao participar, os seres humanos se tornam responsáveis pelo presente em que constroem a ação. E neste sentido, também adotando práticas de subversão.

Entretanto, estas práticas de subversão ocorrem gota a gota, e por isso talvez de forma mais profunda e mais radical que uma revolução. É uma subversão semelhante que ocorre nas células do corpo durante o processo de envelhecimento, que transforma, mas estas mudanças somente são percebidas quando se tornam visíveis aos olhos (MONTERO, 2008). Em complemento, Seoane (1990, p. 176) afirma que:

Participar é querer ser levado em conta na forma em que se tomam decisões, na determinação de quem toma as decisões; participar também é querer ter informação sobre as decisões tomadas; até opor-se e resistir a uma decisão tomada é uma forma de participação. Ao contrário, o que não se constitui como participação nesse terreno é obedecer às decisões já tomadas; estes são atos de submissão política, que podem constituir uma virtude ou uma responsabilidade política, mas não é um ato de participação, posto que não tem a intenção de influenciar a tomada de decisões. A partir deste ponto de vista, a conduta de voto é uma participação necessária, mas não suficiente, como diriam os lógicos. 
Neste sentido, parte-se do pressuposto de que as perspectivas de Montero (2008) e Seoane (1990) dão margem para se compreender algumas dinâmicas subjetivas/objetivas da ação do sujeito em comunidade. Adota-se a premissa que a noção de participação se relaciona nas práticas sociais comunitárias na medida em que se busca significar o ato de participar, isso porque estas práticas ocorrem nas e pelas interações diárias e acontecimentos de suas vidas cotidianas (SANDOVAL, 1994; FREITAS, 2015a).

Na PSCLA falar em participação engloba a cooperação, a solidariedade, a construção e a apropriação por todos os sujeitos que compõem o processo. Neste sentido, Freitas $(2002,2011,2015 b)$ afirma que as relações do cotidiano nunca ocorrem de maneira simétrica, ou seja, nestas relações existem as mais variadas formas de manipulação, de consulta, de divulgação da informação, até a delegação de poder nos grupos e completo controle comunitário.

Concordando com a autora, Demo (2011) afirma que "[...] a participação tende a ser um discurso teórico, para encanto das plateias e das modas. Para se chegar à prática, supõe-se forte ascese, que é mais fácil pregar aos outros, do que concretizá-la em nós" (DEMO, 2011, p. 21). Neste contexto, Montero (2008) propõe que na condução metodológica e analítica do processo de intervenção, torna-se essencial que o profissional/ pesquisador conheça os diversos níveis de participação. Considerando este cenário, Peruzzo (1998) e Montero (2008) organizaram uma classificação dos níveis de participação comunitária descritos a seguir:

1. Participação passiva: neste nível os sujeitos não se envolvem e simplesmente delegam (conscientemente) decisões para outros sujeitos. Nesta situação, o exercício do poder do tipo autoritário (PERUZZO, 1998, p. 78).

2. Participação controlada: este nível pode ser percebido nos relacionamentos entre segmentos da população e movimentos populares com o poder público. Este tipo de participação pode ser conquistado, mas é frequentemente concedido. Possui duas características:

a) Limitação: "a participação controlada é limitada, ou seja, é favorecida e possível somente nos aspectos ou até o ponto que as instâncias detentoras do poder permitem" (MONTERO, 2008, p. 79) e,

b) Manipulação: manipular a comunidade é quando se tenta, de forma não revelada, adequar as demandas da mesma aos interesses de quem está no poder. É também possibilitar uma pseudo participação; como a população escolher algo que já seria feito de qualquer maneira. "Na participação controlada, principalmente a manipulável, o exercício do poder não deixa de ser autoritário, apesar de apresentar-se como democrático. Delegam-se parcelas de poder, descentralizando-o até certo ponto, mas mantêm-se intactas suas principais estruturas" (PERUZZO, 1998, p. 81).

3. Participação poder: neste nível, a "[...] participação democrática, ativa e autônoma propicia, de modo mais completo, o crescimento das pessoas ou das organizações coletivas enquanto sujeitos" (PERUZZO, 1998, p. 81). Esta forma de participação 
não é passiva, nem manipulada, mas nem todas as decisões podem ser democratizadas. Ela se subdivide em:

a) Cogestão: pressupõe a coparticipação, mas as decisões centrais ainda são tomadas pela cúpula hierárquica e;

b) Autogestão: participação direta da população em todas as esferas da vida econômica, social, política, jurídica e cultural (PERUZZO, 1998, p. 83).

Destaca-se que, para Montero (2008), nenhum nível de participação comunitária é mais importante do que outro. Todos são relevantes para que se possa compreender o processo dinâmico nas práticas sociais comunitárias cotidianas. Desta forma, questiona-se: como são configuradas então as práticas sociais comunitárias? As práticas comunitárias são os laços que constituem a comunidade. Dito de outra maneira são as ações comunitárias desenvolvidas por meio de atuação e reflexão que englobam a parceria entre os membros do grupo (MONTERO, 2008; FREITAS, 2003; 2005; 2015b).

Desta forma, as práticas se configuram na comunidade por meio de: a) coesão entre os membros: expressa na solidariedade; b) solidariedade expressa na união entre as pessoas que podem ajudar-se em tarefas difíceis e pesadas, ou em momentos de perigo e necessidade; c) forma de conhecimento e tratamento entre as pessoas: expressa por meio consideração e respeito entre proximidade e distanciamento; d) redes de apoio social: usadas para fins benéficos, esportivos, culturais; e) formas de organização: podem ser específicas em grupos organizados e, no seu grau mais elevado, f) consciência: quando as pessoas se reconhecem como participantes em um processo histórico vivido que afeta a todos apesar das múltiplas diferenças que possam haver no grupo, ou seja, fortalecer a capacidade das pessoas de refletir sobre sua realidade e sobre ela empreender ações transformadoras (MONTERO, 2008).

\section{CAMINHOS DA PESQUISA: UMA INVERSÃO METODOLÓGICA}

Ao eleger-se o tema proposto adotou-se uma postura metodológica direcionada para a pesquisa-intervenção-reflexiva. Para isso foi necessária a inserção no cotidiano dos agricultores/feirantes por meio da posição denominada de interação-dialógica. De forma detalhada, a pesquisa inicial pressupunha apenas a pesquisa na Feira Agroecológica. Entretanto, no decorrer da mesma, foi necessária, a compreensão de forma histórica, documental e de vivência e, a partir disso, a participação comunitária nas práticas da Feira Agroecológica. Neste contexto, foi com esta predisposição que a pesquisa em campo adotou a dimensão metodológica proposta pela Psicologia Social Comunitária (PSC) na perspectiva latino-americana.

Sob este enfoque, Rocha e Aguiar (2003, p. 66) salientam que "[...] a pesquisa-intervenção consiste em uma tendência das pesquisas participativas que busca investigar a vida de coletividades na sua diversidade qualitativa, assumindo uma intervenção de caráter sócio-analítico". Neste sentido, após muitas "idas e vindas" ao campo e por entender que o estudo das práticas comunitárias trata-se de processo complexo, elegeu-se alguns métodos e técnicas que em conjunto permitiram responder ao objetivo proposto. 
Neste processo de escolha e dentro das possibilidades, elegeu-se trabalhar em conjunto com fontes orais e escritas. No que diz respeito às fontes orais optou-se o método de "história oral temática". Esta eleição não foi aleatória, pois foi o campo que direcionou a este processo. Ou seja, a história oral temática permitiu a aproximação com a comunidade Jacutinga e, por consequência, da realidade da Feira Agroecológica e vice-versa.

De acordo com Portelli (2010) há alguns aspectos relevantes na escolha da história oral temática para realizar estudos em comunidade. 0 primeiro deles refere-se ao fato de se "dar voz aos sem voz". Dito de outra forma, os excluídos, os marginalizados, os sem-poder que tem voz, mas não há ninguém que os escute, isso porque esta voz está incluída em um espaço limitado. Por isso, o que os profissionais/pesquisadores geralmente fazem ao eleger este método é "[...] recolher essa voz, amplificá-la e levá-la ao espaço público do discurso e da palavra. Isso é um trabalho político, porque tem a ver não só com o direito à palavra, o direito básico de falar, mas com o direito de falar e ser ouvido, ser escutado" (PORTELLI, 2010, p. 4).

Por sua vez, o segundo aspecto refere-se à relação entre os profissionais/pesquisadores e os narradores orais que estes entrevistam. Dessa maneira, ao usar o método de história oral temática, os profissionais/pesquisadores não podem comparar a comunidade como objetos de investigação/intervenção, mas sim como sujeitos de uma história compartiIhada, de um diálogo. Neste tipo de diálogo, considera-se a entrevista como uma experiência de igualdade. É um momento utópico e também um momento crítico, porque se reconhece a injustiça social que o pesquisador/profissional é responsável por refletir e criticar (PORTELLI, 2010).

Por esse motivo, procurou-se efetuar a leitura do contexto de pesquisa a partir da relação existente entre os elementos psicológicos e históricos presentes na memória (retratados pela história oficial em contraponto com história oral temática), especificamente na comunidade Jacutinga no período da proposição e implantação do Projeto Vida na Roça e na Feira Agroecológica a partir dos os reflexos psicossociais do PVR nesta. Nos resultados desta pesquisa, trazem-se apenas as memórias referentes à participação comunitária na Feira.

O primeiro contato com os feirantes se deu no início do mês de março de 2015. Iniciou-se o processo de investigação-intervenção por meio da observação da Feira no papel de consumidores. Paralelo a estas "idas" à Feira, iniciou-se uma pesquisa documental e bibliográfica buscando subsidiar a Feira historicamente. Obtiveram-se documentos oficiais e materiais produzidos pela Assesoar e várias publicações de professores pesquisadores da Universidade Estadual do Oeste do Paraná (Unioeste). Um detalhe que chamou atenção neste processo foi o fato de que em quase todas estas produções escritas, o discurso era de que o PVR e a Feira Agroecológica eram um projeto de resistência camponesa contra o capitalismo. No mês de maio de 2015, percebeu-se que "idas" a Feira não estavam sendo suficientes para a compreensão de suas práticas comunitárias. Em conversas com os agricultores/feirantes perguntou-se se os pesquisadores poderiam ajudar na Feira para aprender com a experiência. Como tudo na Feira é decidido em reunião no formato de assembleia, por cinco votos a quatro decidiram que os pesquisadores poderiam ajudar.

Todavia, mesmo a observação participante na Feira ainda não foi suficiente. Percebeu-se que haveria necessidade em se conhecer a comunidade Jacutinga assim como o PVR, pois a Feira tratava-se de um resultado dela. Sem a noção de processo inicial, 
as interpretações escritas poderiam ser incongruentes. Conversou-se com os agricultores/ feirantes e eles prontamente se dispuseram em auxiliar. 0 primeiro contato na comunidade ocorreu da forma que eles "aconselharam".

Na primeira semana do mês de junho de 2015, uma das pesquisadoras foi convidada a ir "passear" no final de semana na casa de um dos agricultores/feirantes e no domingo pela manhã foi à missa com a família dele. Após a missa aconteceu um almoço na sede social de igreja, e neste pôde-se ter contato tanto com os agricultores que produzem agroecológicos e participam da Feira, quanto com aqueles que iniciaram no PVR, mas que não deram sequência e também nunca tiveram interesse em participar da Feira.

Após este primeiro contato, esta retornou muitas vezes à Jacutinga e por fim, as pessoas da comunidade já a estavam convidando para os casamentos. Foram nestas ocasiões que se diagnosticou a necessidade de entrevistar alguns agricultores que fizeram parte do PVR em seu início, mas que se desligaram do projeto e não fizeram/fazem parte da Feira Agroecológica. Além disso, por consequência, precisava-se ouvir também a Assesoar neste processo. Para tanto, realizou-se ao todo nove entrevistas não estruturadas em campo: a) uma com técnico/funcionário da Assesoar; b) quatro entrevistas com agricultores/feirantes que residem na comunidade Jacutinga e fazem parte da Feira há pelo menos 17 anos e, c) quatro com agricultores residentes na comunidade Jacutinga que fizeram parte do PVR desde o início, mas não permaneceram.

A duração média das entrevistas foi de uma hora e todas as falas foram gravadas e transcritas. Anotações a respeito das interações, reações, dificuldades e eventuais manifestações das entrevistadas foram registradas na lateral das transcrições localizando os momentos e possíveis razões das suas expressões. Além disso, registrou-se em diário de campo muitos relatos informais, inclusive dos(as) agricultores(as) que aceitaram gravar as entrevistas. Quando o gravador era desligado os entrevistados explicavam várias situações que no momento da gravação não faziam.

Por sua vez, o processo analítico dos dados deu-se a partir do que propõe o método da História Oral, ou seja, a partir da apropriação pelas pesquisadoras do que foi narrado, ouvido e sentido no campo de pesquisa. Desta forma, a partir dos dados coletados na pesquisa documental (história oficial) realizou-se uma contraposição por meio dos discursos (orais temáticos) dos entrevistados. Os resultados apresentados na pesquisa são consequência deste processo.

\section{A FEIRA AGROECOLÓGICA: PARTICIPAÇÃO COMUNITÁRIA?}

A Feira Agroecológica, conforme discurso oficial da Assesoar foi criada em 1997, pelos agricultores da comunidade Jacutinga que fundaram a Associação Amigos da Natureza. Ela é realizada regularmente todas as sextas-feiras pela manhã há 18 anos no Bairro Cango, local onde a ONG está situada. Conforme relata a história institucionalizada, a Feira foi criada de forma coletiva pautada na noção de agroecologia "[...] como estratégia política e prática de intervenção visando o enfrentamento aos processos de territorialização do agronegócio e a construção de referências em âmbito da produção, da educação e da organização camponesa" (ASSESOAR, 2015, p. 17). 
Por meio de pesquisa documental, todavia, percebeu-se que esta ONG, ao longo de sua história, construiu uma metodologia de trabalho que combina a ação em campo com elementos pastorais da Igreja Católica. Nesse processo ela também estabeleceu alguns critérios para a identificação das pessoas que fariam parte de seus projetos. Explicando de outra maneira, ao eleger os participantes de seus projetos, a Assesoar classifica os sujeitos de acordo com sua capacidade de intervir na realidade em que vivem. Sendo assim, percebe-se que este tipo de atuação considera os sujeitos a serem "beneficiados" por seus projetos em duas categorias básicas: os passivos e os criativos.

Em linhas gerais, a ONG infere que os sujeitos sociais passivos assumiriam que o mundo em suas múltiplas esferas já está consolidado, ou, que cabe a outros fazerem as alterações que pensam ser necessárias. Por sua vez, para os sujeitos sociais criativos, nada está parado ou definido. São estes os que lutam para transformar o mundo, que se esforçam para recriar as condições de existência, são os que militam por causas e nessa militância transformam o seu cotidiano (ASSESOAR, 1998).

Neste sentido, quando se perguntou ao técnico da Assesoar sobre como se deu o processo de criação da Feira Agroecológica este afirmou:

A Feira é todo resultado do processo de formação que os agricultores receberam no PVR. Para você ver como este projeto era bom. Os agricultores participavam da formação, recebiam instrução. Eles estavam perdidos, precisavam de uma condução. Daí, pensamos ser a Feira uma ideia legal, pois, principalmente as mulheres teriam 'um cuido' e os homens veriam que seria mais fácil, por assim dizer, mudar do convencional para o ecológico. Eles teriam a Feira para poder repassar seus produtos. Isso era um incentivo [...]. A gente chegou na formação e falamos: vamos pensar em algo que vocês poderiam fazer para que pudessem repassar a produção ecológica e terem um dinheirinho. A gente já estava com a Feira na cabeça, mas deixamos eles darem a ideia (Entrevista 9, 2015).

Por meio do fragmento discursivo observa-se que na concepção metodológica assumida pela Assesoar no PVR e por consequência em suas ações (dentre elas a Feira), esta considerou os agricultores sujeitos passivos, prontos para serem conduzidos na realidade e na criação da Feira. A Feira já era ideia da Assesoar, mas a ONG deixou com que os produtores pensassem que essa era ideia deles:

Na nossa formação do PVR, que era à noite, a gente ia. A gente estava cansado, mas ia participar, até porque era nesta hora que gente encontrava algum técnico para tirar as dúvidas na produção. Foi difícil mudar do convencional para o ecológico e os técnicos eram poucos. Quase todos os grupos falaram no final da ideia da Feira, e foi assim que a Feira surgiu (Entrevista 4, 2015).

A Feira surgiu dos nossos cursos. 0 pessoal da Assesoar afirmou que estava preocupado porque a gente teria um produto que os mercados da cidade não iriam querer, porque seria mais caro que os produtos com veneno. Então, fizemos uma reunião e uma atividade e o pessoal do curso achou melhor criar a Feira (Entrevista 2, 2015). 
Comparando os fragmentos discursivos do técnico da Assesoar com os dos feirantes, vemos como se deu a participação na criação da Feira: por meio da participação controlada (PERUZZO, 1998; MONTERO, 2008). Esta ocorreu de forma que a Assesoar lançasse a proposição da Feira e incutisse nos agricultores que a ideia foi deles no coletivo. Neste aspecto, observa-se o controle da ação na relação de poder "velado", em que o sujeito acredita na participação das decisões, mas foi conduzido a elas.

Freitas $(2009 ; 2011 ; 2015 a)$ diz que isso é muito comum. Ela denomina este tipo de ação como sendo uma "inclusão excludente". Dito de outra forma, os agentes externos pautados no "mito da participação" assimilaram em seus discursos que a comunidade Jacutinga realmente propôs a criação da Feira como sendo uma "necessidade comunitária". Com isso, venderam para os agricultores da comunidade uma pseudo ideia de que as demandas desta população estavam todas contempladas neste projeto. E como se deu esse processo de participação comunitária? O técnico da Assesoar relata:

Para atingir este nível de participação, a gente acreditava que o caminho mais curto era o da valorização da comunidade. Primeiro nós realizamos reuniões com os agricultores das linhas, e depois, de assembleias mais ampliadas para a definição das demandas apontadas pelos agricultores. Tudo com a participação de todos... a gente procurava estabelecer uma relação próxima entre a coordenação (composta por agricultores e representantes das entidades parceiras) e as reuniões realizadas com a comunidade. Era dessas reuniões que saíam as demandas e as necessidades dos agricultores (Entrevista 9, 2015).

Conforme fragmento discursivo se observa que na ótica da ONG as ações locais constituíam-se numa forma estratégica de pensar e realizar o desenvolvimento. Esse processo é visto como uma forma de garantir efetiva deliberação e participação da população interessada.

Todavia, para a comunidade Jacutinga, a proposição da feira por meio do PVR não foi recebida de forma tão "construída e participativa" como o fragmento discursivo do técnico relata. Este aspecto pode ser percebido por ocasião da pesquisa realizada em campo. Ou seja, durante vivência na comunidade, acompanhado as rotinas dos agricultores/ feirantes percebeu-se que ao tocar no assunto "Projeto Vida na Roça" os agricultores se sentiam incomodados, mudavam de assunto ou se calavam.

Como exemplo, podemos citar uma comemoração de aniversário ocorrida no paviIhão da igreja da sede da comunidade, momento em que conversamos com vários agricultores que inicialmente fizeram parte do PVR, mas, com o passar do tempo não permaneceram. Durante este evento, os agricultores relataram várias situações, as quais foram relatadas no Diário de Campo, porque percebemos muita resistência e desconfiança por parte deles em relação a "pesquisadores vindos de fora da comunidade" (DIÁRIO DE CAMPO, 2015).

Dentre as situações conflituosas, estes agricultores contaram que por ocasião da proposição do PVR se sentiram enganados, porque segundo eles a

ASSESOAR, e outras entidades foram até a comunidade e fizeram um 'carnaval' (palavras deles) sobre os benefícios do projeto, mostraram dados, 
apresentaram fotos, fizeram discursos, mas trouxeram os objetivos prontos. Nas reuniões eles apresentaram o projeto com seus objetivos e fizeram os agricultores acreditar que a ideia era deles (DIÁRIO DE CAMPO, 2015).

A situação relatada é confirmada pela entrevistada 2 que reside a 30 anos em Jacutinga e participa a 18 anos da feira:

Eu concordo com meus vizinhos, o projeto foi vendido como 'milagreiro' mas a coisa não foi bem assim. Lembro o primeiro dia que vieram fazer reunião na comunidade. Foi aquela empolgação, fizemos grupos, eles davam as tais metas e a gente discutia e depois apresentava para todos. Mas, eles tinham tudo definido já [...] apenas davam a impressão para nós (um bando de alemão chucro) que nós decidia. Agora, quando eles (a Assesoar) queriam trazer um monte de autoridade, alunos para nossa comunidade e mostrar que tinham feito tal projeto, aí sim, a gente era Deus para eles [...] essa é a mágoa. Jacutinga só aparecia quando tinha que mostrar um projeto novo, que nem fomos nós que pensamos. Eles vieram com isso pronto. Agora na hora que a gente precisava de um apoio, orientação para tentar um crédito, aí eles sumiam (Entrevista 2, 2015).

Por sua vez, o entrevistado 6 que reside há 42 anos em Jacutinga e não faz parte da feira, mas planta produtos mistos (agroecológicos e convencionais) em sua propriedade afirmou:

Neste projeto nossa comunidade foi feita de trouxa. Penso que eles [ASSESOAR] pensavam que a gente era trouxa. Era gente entrando, gente saindo da nossa comunidade. Perguntando coisas, se metendo em tudo. Eles nem tiveram o trabalho de perguntar se a gente queria aquilo tudo (Entrevista 6, 2015).

Os relatos apresentados trazem à tona como a ASSESOAR desenvolveu o processo de convencimento dos agricultores da comunidade de Jacutinga na adoção do PVR. Neste processo, esta ONG adotou como estratégia de convencimento o formato "tradução" (MONTERO, 2003, p.67), ou seja, aquele que não respeita "para que" e "em benefício de quem" o saber é produzido e quais são seus efeitos sociais da intervenção.

Dessa maneira, o processo de tradução dos agentes externos para os agricultores de Jacutinga ocorreu mediantes reuniões que obedeciam a um ritual, amparado em métodos de dinâmicas de grupo, em nosso entendimento psicologizantes, por meio de orientação técnica, discussões políticas e de formação comunitária.

Assim, durante as observações realizadas em campo, entendemos que a relação estabelecida com a comunidade Jacutinga deu-se por meio da participação controlada de forma manipulativa, ou seja, aquela quando se tenta, de forma não revelada, adequar as demandas da comunidade aos interesses de quem está no poder. É também possibilitar uma pseudoparticipação; como a população escolher algo que já seria feito de qualquer maneira.

Neste formato, "[...] a participação é controlada, principalmente manipulável, sendo que o exercício do poder não deixa de ser autoritário, apesar de apresentar-se como 
democrático. Delegam-se parcelas de poder, descentraliza-se até certo ponto, mas mantêm-se intactas suas principais estruturas" (PERUZZO, 1998, p. 81).

Após a formação e tendo a ideia da criação da Feira sido acolhida de forma "participativa" pelos agricultores, a ONG em conjunto com parcerias locais iniciou a busca por um local para sua realização, bem como organizou um projeto extensionista para captar recursos para a organização das barracas na feira. 0 técnico relata como ocorreu esta parceria:

O bairro Cango foi escolhido após muita discussão com os outros parceiros. Mas nós da Assesoar preferimos o Cango. Lógico, ficava mais perto de nós. Além disso, poderíamos ver como os agricultores fariam com a feira. Ficaríamos no aguardo. Sem eles perceberem, acabariam fazendo tudo como nós idealizamos [...]. Tem mais uma questão. O Cango é o bairro que homenageia os colonos, isso seria fantástico como promoção da feira (Entrevista 9, 2015).

0 relato discursivo acima apresenta dois aspectos que precisam ser esclarecidos. 0 primeiro deles refere-se à escolha do local para a realização da Feira. Não por acaso a Assesoar elegeu o bairro da Cango. Esta escolha se deu por dois motivos: a) por ser próximo à sua sede e isto facilitaria o acompanhamento das atividades por meio de um controle subjetivo. $\mathrm{E}, \mathrm{b}$ ) por ser o bairro da Cango uma homenagem aos pioneiros colonizadores da região. Conforme Alves (2008), quem caminha pelo Bairro da Cango, em Francisco Beltrão, depara-se com um quadrilátero de símbolos regionais que se mesclam no espaço com instituições nacionais. Cada um deles solidificado e construído de diferentes formas, mas todos complementares entre si. A Figura 1 apresenta estes símbolos.

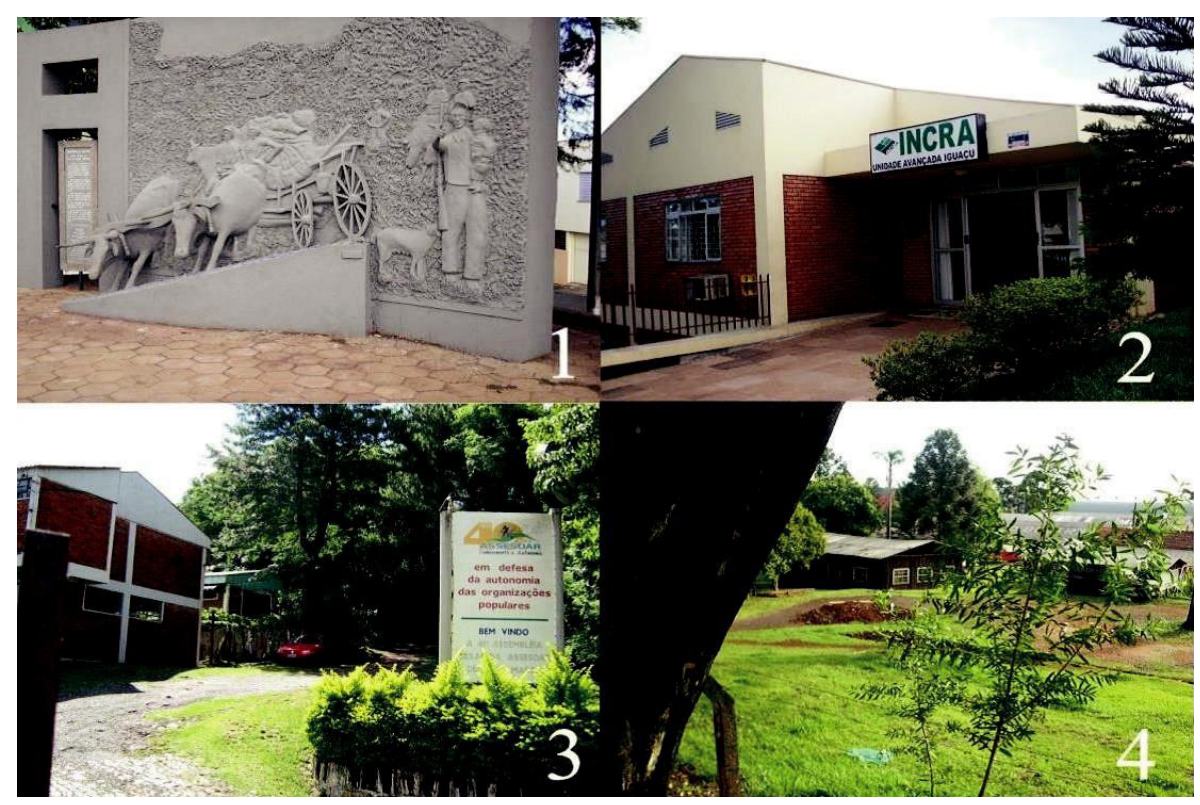

Figura 1 - Quadrilátero do Bairro da Cango

Legenda: 1. Monumento da Praça de Colonização; 2. Sede do Incra; 3. Sede da Assesoar; 4. Exército (Antiga Sede Da Cango).

Fonte: As autoras (2015) com base na descrição de Alves (2008). 
0 primeiro é o monumento aos colonos gaúchos, criado em 2002, durante as comemorações dos 50 anos de Francisco Beltrão. Nele, o poder público quis homenagear a chegada dos colonos, para fortalecer o mito do pioneirismo e da bravura destes. Em um relevo de concreto, um homem com pés descalços segura no braço esquerdo uma criança e, a tiracolo, no ombro direito, uma espingarda.

Com a mão direita aponta para o infinito, como se dissesse: "Chegamos à terra prometida". Ao lado do homem, um carro de boi traz a sua família e os seus pertences. Ao fundo, como uma barreira superada, uma densa floresta de pinheiros sugere que nada mais havia na floresta, além de árvores a serem derrubadas para ceder lugar às plantações ${ }^{9}$.

Em frente a este monumento, dividindo a mesma praça, o "esqueleto" amarelo da patrola pertencente à Colônia Agrícola General Osório (Cango), responsável pela terraplanagem das primeiras estradas da região, simbolizando a chegada do progresso. A Cango foi criada em 1943 pelo Governo Federal, com o objetivo de atrair os colonos sulistas para ocupar as terras do Sudoeste do Paraná, e segundo Wachowicz (1985) formou um modelo de colonização extremamente atrativo aos migrantes do Rio Grande do Sul e de Santa Catarina, pois subsidiava o início de vida do agricultor em sua nova propriedade.

Defronte à praça do monumento, encontra-se o prédio do Instituto Nacional de Colonização e Reforma Agrária (Incra), construído em linhas retas, no estilo modernista despojado e austero, cuja monotonia só é quebrada pela presença de agricultores sem-terra com suas bandeiras vermelhas. Ao lado do Incra, dividindo o mesmo terreno, o $16^{\circ}$ Esquadrão de Cavalaria Mecanizado de Francisco Beltrão.

Por sua vez, a pouco mais de cem metros dali, aos pés do Morro do Calvário, a sede da Assesoar, constantemente cheia de agricultores vindos de toda a região Sudoeste para frequentar reuniões políticas, participar de cursos técnicos de formação, entre outras. Esta ONG esteve presente em diversas fases da constituição do Sudoeste e atualmente trabalha no que ela chama de geração de referência para as políticas públicas (ALVES, 2008).

E, finalmente, completando o quadrilátero, o Esquadrão do Exército ocupa o terreno no qual originalmente funcionava a Cango, a promotora original da colonização da região na década de 1940. No seu perímetro, ainda é possível encontrar as velhas construções de madeira da antiga companhia. Nesse sentido, ao andar-se pelo bairro da Cango, observa-se nesse quadrilátero a cristalização de muitas das questões da história da posse da terra no Sudoeste do Paraná. Neste sentido, não foi aleatoriamente que o processo de escolha deste bairro para a constituição da Feira Agroecológica se deu.

O segundo aspecto que precisa ser esclarecido é o fato da prefeitura, no início do PVR, ter sido parceira na proposição da Feira no bairro da Cango. Neste período, os

9. No Sudoeste paranaense (que faz parte Francisco Beltrão, cidade do estudo realizado) antes da colonização (década de 1920 a 1940), conforme Wachowicz (1985) residiam aproximadamente 6000 caboclos que dividiam com os índios Guarani um vasto território. Tais aspectos, baixa densidade populacional e pouca conexão com o mercado, marcaram o discurso construído após a década de 1970 que considerou a região como "terra de ninguém". Esse discurso foi considerado como um dos elementos da "bandeira" do pioneirismo como sendo uma interpretação da história oficial, todavia, há relatos colhidos em diferentes localidades da região os agricultores pioneiros confirmaram a presença de indígenas na região e contribuição dos caboclos nos primeiros anos de colonização. E nesse processo a Companhia Agrícola General Osório (Cango). Esta companhia deveria promover a colonização estatal do Sudoeste do Paraná e assim o fez (WACHOWICZ, 1985; ALVES, 2008). 
interesses políticos e a parceria no PVR sedimentaram esta Feira. Todavia, conforme discurso institucionalizado, a Assesoar afirma que, a partir de 2003, a prefeitura pretendia inserir a Feira da CANGO no centro da cidade. Porém, os autores salientam que na feira do centro da cidade, considerada a maior do município não há um direcionamento político mais específico em matéria de agroecologia. Em outras palavras, esta feira possui uma política de incentivos do poder público local (prefeitura e outros agentes públicos), mas há um conflito entre as perspectivas convencional e agroecológica, de produção e de organização da feira, fator este que levou alguns produtores a romperem com esta proposta e estruturarem outra, exclusivamente destinada à comercialização de produtos agroecológicos. Entretanto, mais do que uma falta de direcionamento entre agroecologia versus convencional, é preciso entender que há um conflito político entre prefeitura e Assesoar que foi constituído historicamente desde o PVR. E este conflito político se refletiu e se reflete até hoje na Feira Agroecológica.

Após a definição do local, a Feira Agroecológica deu início a suas atividades em 1997, de forma improvisada, isso porque a outra instituição parceira ainda não havia conseguido todos os recursos necessários para acomodação física desta. Porém, mesmo com este improviso, a Assesoar decidiu iniciar as atividades da Feira. O técnico da ONG relata:

Nós não queríamos esperar muito, pois os agricultores estavam empolgados e não queriam esperar mais, assim, decidimos começar com barracas simples, mas bem organizadas e limpas. A gente deu esta estrutura e deixamos os feirantes se organizarem como queriam, não interferimos neste processo. [...] Mas, fomos dando dicas, indicando posições das melhores barracas, enfim, fazendo com que os agricultores pensassem que eles organizavam, mas era a gente que dava o tom (Entrevista 9, 2015).

O fragmento discursivo demonstra como a Assesoar se coloca na posição de referência no processo organizativo interno dos feirantes no início da feira. Isso se chama tutelamento! Explicando melhor, a ONG tinha um posicionamento sobre a incapacidade dos agricultores se organizarem e por isso precisavam de um acompanhamento. Todavia, quando perguntado aos agricultores/feirantes sobre as atividades organizativas no início da feira, estes responderam:

Um dia chegaram e disseram nos cursos de formação: mês que vem vai iniciar a feira. Vamos ver quem quer participar e que produtos vocês têm para levar. Os agricultores se assustaram com isso. Muitos não tinham condições de transportar seus produtos, outros estavam com a agricultora convencional e ecológica. E outros não queriam participar da Feira. No final das contas, só nove famílias se dispuseram a ir. A nossa foi uma delas. Eu queria ir, mas meu marido e meus filhos foram contra. Mesmo assim eu cheguei em casa e separei o que poderia vender e fui (Entrevista 3, 2015).

No curso de formação fiquei assustada. Tudo foi muito rápido. Nossa família tinha pouca coisa em casa para comercializar, mas decidimos ir. A gente tinha um fusca. No primeiro dia da Feira carregamos o fusca e fomos. Foi um terror, eu não sabia como vender, nem que preço cobrar. 0 pessoal da Assesoar disse que não ia se meter nisso, a gente se sentiu abandonado (Entrevista 4, 2015). 
Por meio do fragmento discursivo da entrevista 3, confirma-se que o processo organizativo ocorreu de forma improvisada, ou seja, tendo a Assesoar definido o local da Feira, foi à comunidade e durante o curso de formação informou aos agricultores sobre 0 início das atividades. Tal atitude causou surpresa e medo nos agricultores, fator este que contribuiu para que poucas famílias decidissem participar dela.

Por sua vez, o discurso da entrevista 4 relata, além do medo em participar da Feira, o abandono da Assesoar naquele momento de criação da Feira. Outra dificuldade no processo organizativo apontada pelos agricultores/feirantes no início refere-se ao o transporte dos produtos das famílias para a comercialização na feira. Ou seja, além da família da entrevistada 3 (que tinha um fusca) as outras oito famílias não tinham carro, tendo que transportar seus produtos no ônibus rural que fazia a linha do distrito Jacutinga duas vezes por dia, pela manhã e ao final da tarde. 0 fragmento discursivo a seguir apresenta esta dificuldade.

A gente sofria muito para levar os produtos para a Feira. Fomos falar com a Assesoar e eles disseram que não podiam ajudar neste sentido. Quase nossa família desistiu. Era muito sofrido andar $35 \mathrm{~km}$ de manhã com sacolas cheias de produtos no ônibus e a Feira termina $12 \mathrm{~h} 00$ e a gente tinha que esperar até o fim da tarde para voltar para a comunidade [...] Eu ia desistir. Principalmente porque no inverno é frio, chuva. E eu tava sempre lá, não queria nem saber. Levava uma muda de roupa, duas. Molhava, as mulheres ficavam com dó, vinham lá traziam casaco, na outra sexta levava de novo, porque ficar molhado o dia inteiro é muito tempo (Entrevista 2, 2015).

O discurso confirma as dificuldades no transporte dos produtos para Feira. Neste sentido, o entrevistado destaca que solicitaram apoio logístico para a Assesoar e não obtiveram. Três anos se passaram e somente em 2000 o projeto de uma universidade parceira foi aprovado e a partir disso houve uma reestruturação física da Feira que permanece até hoje.

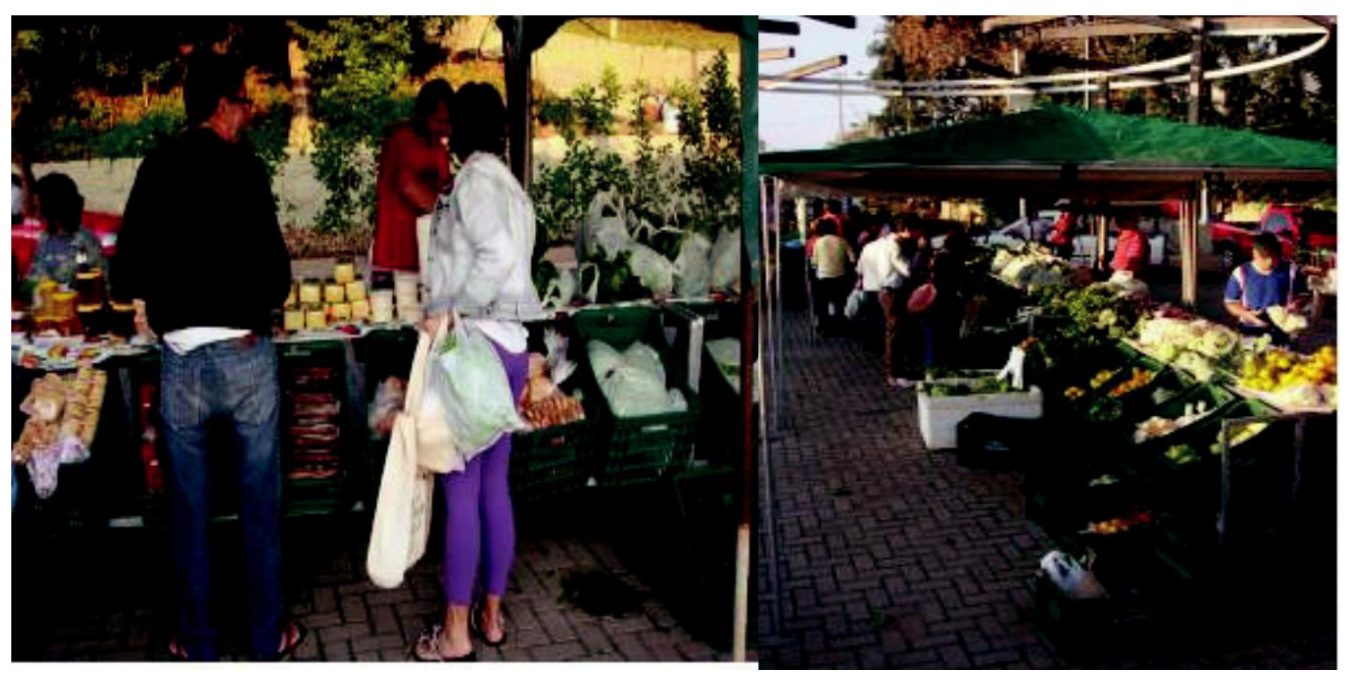

Figura 2 - Feira Agroecológica Cango, 2015

Fonte: Acervo Assesoar (2015). 
Ao observar a Figura 2, se percebe ser ainda uma estrutura simples em formato de gazebos, semanalmente montada e desmontada, que nove famílias ainda fazem parte. Desde o início até 2015 (data da pesquisa), a Feira varia o destaque para a diversidade de produtos. Além do mais, a relação de venda direta potencializa a interação e a construção de sistemas de confiança: "quem produz aparece" e é reconectada a relação entre produtor e consumidor. Quanto ao processo organizativo, perguntou-se se ainda hoje a Assesoar auxilia os agricultores/feirantes. As respostas a esta questão são descritas a seguir,

Mesmo quando queremos mudar algo, fazemos uma reunião dos nove e discutimos os assuntos e quando não concordamos fazemos votação (risos). Mas no fim, a gente sempre procura a Assesoar para que ela auxilie, na verdade, diga que a decisão está correta (Entrevista 2, 2015).

O fragmento discursivo apresenta dois aspectos relevantes a serem destacados. 0 primeiro diz respeito ao formato como as decisões são tomadas pelos agricultores participantes no âmbito interno organizativo da feira. Ou seja, ainda hoje seguem o modelo metodológico implantado no PVR: assembleia (reunião) - discussão - votação. Sem se dar conta, os agricultores/feirantes adotam o modelo proposto pela Assesoar e fazem isso de foram inconsciente. Além disso, eles dependem que a Assesoar referencie sua decisão, fato este que dá uma falsa ideia de coletividade.

Neste prisma, temos o segundo aspecto que remete ao fato dos agricultores/feirantes reafirmarem em seus discursos que a Assesoar não conduz os processos organizativos da Feira, mas a denominam como ponto de referência para solução dos conflitos ou dúvidas. Durante a inserção das pesquisadoras como feirantes, se observou diversas ocasiões em que os agricultores procuram os funcionários da ONG para "trocar ideias". Em diversas vezes fizeram comentários como: "estou com dúvidas sobre o preço dos produtos, o pessoal da Assesoar deve saber", ou ainda, "[...] o pessoal da Assesoar sempre nos ajuda, tenho que ver o que eles pensam sobre isso" (DIARIO DE CAMPO, 2015)

Em um destes relatos informais, contaram que no final dos anos 2000, num contexto de reestruturação da Associação de Agricultoras e Agricultores Ecológicos, os feirantes acordaram em encerrar as atividades da Feira da Cango e escoar seus produtos no mercado da cooperativa, sendo esta uma estrutura fechada, com locais mais apropriados para dispor e armazenar os alimentos. Realizaram esta experiência por três meses, porém a venda diminuiu significativamente, porque os consumidores, segundo relatos, "[...] não tinham identidade com a União Nacional das Cooperativas de Agricultura Familiar Integrada (COOPAFI), não se habituaram a comprar na nova estrutura, mesmo situando-se a trezentos metros do local onde realizava se a feira" (DIÁRIO DE CAMPO, 2015).

Entende-se, a partir da ótica da PSCLA, a venda diminuiu significativamente porque a dimensão psicossocial de convivência entre produtor-consumidor se alterou. Em outras palavras, quando a Feira era realizada em espaço livre, antes da mudança, para o espaço fechado, tinha-se a questão subjacente voltada para a sociabilidade, degustação de produtos, reeducação de hábitos alimentares, difusões de informações, e a constituição de laços de consumidores ecológicos que se diferenciam dos convencionais, quando buscam alimentos livres de resíduos tóxicos. 
Todavia quando a Feira mudou-se para um espaço fechado, houve o desaparecimento dessa relação pessoalizada de compra. Dito de outra forma, no mercado fechado a relação de compra passou a ser realizada de forma impessoal, eliminando-se a característica central da convivência interpessoal. Para solucionar esta situação perguntou-se o que os agricultores/feirantes fizeram em relação a situação. Responderam: "procuramos a Assesoar para saber o que fazer. A partir das orientações deles voltamos a realizar a Feira em espaço livre na Cango e saímos da cooperativa" (DIARIO DE CAMPO, 2015).

Desta forma, esta postura dos agricultores/feirantes denota que a relação de extrema dependência da Assesoar (mesmo que em seus discursos estes não percebam isso), é um reflexo direto da forma como o PVR foi proposto e implementado pela ONG. Ou seja, a ideia de que a organização da Feira foi/é dos próprios agricultores, formulada e gerida por eles, garantiu/garante que esta tenha sido/é conduzida de "forma harmoniosa", "democrática" e "participativa".

Esta relação pode ser considerada perversa em sua forma subjetiva a partir do momento que a ideia de participação comunitária é vendida pelos próprios agricultores/ feirantes em seu cotidiano. Dito de outra forma, eles acreditam que foram/são protagonistas de uma forma de resistência anti-hegemônica quando na realidade são coadjuvantes de uma proposta de intervenção nada participativa. Isso porque em quase todas estas produções escritas, o discurso era de que o PVR e a Feira Agroecológica eram um projeto de resistência camponesa contra o capitalismo.

\section{REFLEXÕES FINAIS: PARA CONTINUAR A PENSAR...}

Conforme apresentado, foi no formato de uma organização participativa e de práticas comunitárias que a Assesoar teve sua matriz fortalecida. Ou seja, junto aos diversos grupos populares, que passaram a ser reconhecidos e aceitos para o desenvolvimento de programas de intervenção em comunidade. Todavia, para a PSCLA este formato (tão valorizado no mundo contemporâneo voltado para o "pensamento único" apresenta incoerências que valem ser destacadas.

A primeira incoerência diz respeito a não disponibilidade de identificação dos agentes externos sobre o cotidiano da comunidade a ser contemplada com uma proposta intervencionista. Dito de outra forma, para uma proposta intervencionista pautada na égide da PSCLA, é necessário adquirir conhecimentos que ultrapassem uma análise aparencial e descritiva, viabilizando a compreensão dos aspectos epistemológicos e políticos, nos planos macro e microssociais da vida cotidiana.

Ao propor o PVR e como consequência disso a Feira Agroecológica para a comunidade Jacutinga, a Assesoar não se predispôs a isso. Muito pelo contrário, idealizou a comunidade por meio de valores comunitários paroquiais.

Em outras palavras, percebemos que embora o PVR não contasse com a interferência direta da igreja entre as entidades participantes, essas atividades se assemelhavam às encontradas nas Comunidades Eclesiais de Base (CEB's), da Igreja Católica. 0 princípios das CEB's fundamentam-se no mito da "comunidade perfeita, homogênea, cristã e pura" 
(MONTERO, 2008). Tais princípios são completamente opostos à perspectiva apresentada na Psicologia Social sob enfoque latino-americano.

A segunda incoerência refere-se ao fato de que a Assesoar, por adotar a posição favorável ao projeto ecológico camponês, utilizando conceitos de "desenvolvimento sustentável" e "agroecologia" dentro de um recorte político específico, atribuiu o caráter do PVR e da Feira Agroecológica como sendo inédito e inovador pelo inusitado do tema dentro de um contexto de efervescência da década de 1990.

A terceira incoerência refere-se à identificação do tipo de projeto de sociedade e de ser humano que foram contemplados nas concepções e práticas propostas neste projeto. Mesmo que este tenha apresentado em sua descrição pautar -se nos eixos que direcionam a Teologia da Libertação, o sujeito social não foi valorizado em sua proposta comunitária.

Para a PSCLA em trabalhos efetivamente comunitários, os profissionais/pesquisadores devem incentivar a participação, segundo a literatura, quanto a: a) lugar e poder de decisão dos sujeitos sociais envolvidos na comunidade, com relação aos rumos do trabalho, recursos e estratégias a serem utilizadas; b) tipo de conhecimento que possui e a valorização que recebe por isto nas relações; c) perspectiva de trabalho que as relações acabam defendendo, em termos do continuum individual-coletivo.

$\mathrm{Na}$ proposição da Feira Agroecológica estes elementos não foram levados em consideração. Ou seja, a Assesoar fomentou uma falsa noção de participação democrática, propiciando um interfluxo de questões, para dar a impressão que as decisões foram tomadas coletivamente, mas esta ocorreu dentro de marcos pré-estabelecidos. A Feira é considerada pelo discurso oficial como uma proposta de inclusão social, de resistência ao agronegócio, mas o que se presenciou foi um projeto estruturado a partir da ótica do agente externo. Há uma perspectiva de solidariedade e cooperação entre os feirantes, todavia esta é superada quando há algum problema a ser resolvido e eles atribuem esta responsabilidade à ONG, por meio de consulta.

Desta forma, entende-se que a Feira é resultado de um projeto pontual e curativo que visou a "melhoria" da qualidade de vida dos agricultores da comunidade, sem que isto, necessariamente, implicasse no aumento da participação e consciência política dos envolvidos no processo. Neste prisma, visualiza-se que os sujeitos sociais perderam seu papel de protagonistas e assumiram o lugar de expectadores das ações institucionalizadas pela Assesoar. Nestas condições, a participação foi meramente nominal e seu caráter democrático foi reduzido ou anulado, de forma que não se pode ver, na sua totalidade, os pressupostos metodológicos e epistemológicos da PSCLA no projeto intervencionista proposto e implantado.

\section{AGRADECIMENTOS}

Agradecemos o apoio e financiamento da Fundação Araucária de Apoio ao Desenvolvimento Científico (FAPPR) e Tecnológico do Paraná e da Coordenação de Aperfeiçoamento de Pessoal de Nível Superior (CAPES) para a consecução da pesquisa. 


\section{REFERÊNCIAS}

ALCADIPANI, R.; ROSA, A. R. O Pesquisador como o outro: uma Leitura Pós-colonial do "Borat" Brasileiro. RAE - Revista de Administração de Empresas, v. 50, n. 4, 2010. p. 371-382.

ALMEIDA COSTA, F. H. E (ed.). International Community Psychology: Community approaches to contemporary social problems (v. 1). Puebla: Universidad Iberoamericana de Puebla, 2011.

ALMEIDA, L. P. de. Para uma caracterização da psicologia social brasileira. Psicologia, Ciência \& Profissão, v. 32, n. 1, 2012. p. 124-137.

ALVES, A. F. Do Desenho à Implementação de Projetos de Desenvolvimento Rural Sustentável: Interfaces e Negociações no Projeto Vida na Roça (Paraná). 2008. 234p. Tese (Doutorado). Universidade Federal de Santa Catarina. Florianópolis, 2008.

ARENDT, R. J. J. Psicologia comunitária: teoria e metodologia. Psicologia: Reflexão e Crítica, v. 10, n. 1. 1997. p.7-16.

ASSESOAR. Avaliação final do Projeto Vida na Roça. 1998. Disponível em: http://assesoar. org.br/. Acesso em: 13 de fevereiro de 2015.

Desenvolvimento comunitário. Encontro com a comunidade de Jacutinga. 1996. Disponível em: http://assesoar.org.br/. Acesso em: 13 de fevereiro de 2015.

AVELAR, L. Participação política. In: AVELAR, L.; CINTRA, A. O (orgs.). Sistema político brasileiro: uma introdução. São Paulo: Editora Unesp, 2007.

BARROS, A.; CARRIERI, A. de P. O cotidiano e a história: construindo novos olhares na Administração. RAE - Revista de Administração de Empresas. v. 55, n. 2, 2015. p. 151-61.

CEDEÑO, A. L. Reflexões sobre a autogestão e psicologia comunitária na América Latina. Psicologia Social e Institucional. v. 1, n.2, 1999. p. 13-25.

COSTA, G. P. Cidadania e participação: impactos da política social num enfoque psicopolítico. Curitiba: Juruá, 2009.

DEMO, P. Do beneficiário ao cidadão. In: Política social do conhecimento: sobre futuros do combate à pobreza. Petrópolis: Vozes, 2011.

FAÇANHA, C. R. Um estudo psicossocial sobre as práticas profissionais dos agentes comunitários em saúde na grande Curitiba: subsídios da educação e da psicologia social comunitária. 2006. Dissertação (Mestrado em Educação). Curitiba, Universidade Federal do Paraná. 2006.

FARIA, J. H. Estudos organizacionais no Brasil: arriscando perspectivas. RBEO, v.1, n. 1, 2014. p.1-10.

FARR, R. M. As raízes da psicologia social moderna. 6. ed. Rio de Janeiro: Vozes, 2004.

FREITAS, M. F. Q. de. Práxis e formação em psicologia social comunitária: exigências e desafios ético-políticos. Estud. psicol (Campinas), v. 32, n. 3, 2015a. p. 521-532. 
FREITAS, M. F. Q. de. Desafios éticos na prática em comunidade: (des)encontros entre a pesquisa e a intervenção. Pesquisas e Práticas Psicossociais, v. 10, n. 2, 2015b, p. 242253.

. Community Social Psychology as Political Education and Awareness-Raising: Resistances and Possibilities in Everyday Life-Suggestion for a Model of Analysis. International Community Psychology, 2011, p. 77.

. ¿(Des)Encuentros entre la intervención y investigación comunitarias? Dilemas éticos en la perspectiva de la psicología social comunitaria. In: VAZQUEZ RIVERA et al (org.). Psicología comunitaria internacional: agendas compartidas en la diversidad. Porto Rico: Editorial: Actividades de Formación Comunitaria, 2009, p. 151-17.

. (In)Coerências entre práticas psicossociais em comunidade e projetos de transformação social: aproximações entre as psicologias sociais da libertação e comunitária. Psico, Porto Alegre, PUCRS, v. 36, n. 1, p. 47-54, 2005.

. Dimensões da Exclusão e da Participação na Vida Cotidiana: Perspectiva da psicologia Social Comunitária Latino-Americana. In: Schimdt, M.A. \& Stoltz, T (orgs.). Educação,Cidadania e Inclusão Social. Curitiba: Aos Quatro Ventos, 2006.

. Psychosocial practices and community dynamics: meanings and possibilities of advance from the perspective of the engaged social actors. The International Journal of Critical Psychology. Estados Unidos, v. 9, p. 107-124, 2003.

. Intersecciones entre sentido de comunidad y vida cotidiana. In: PIPER, I (comp.). Políticas, Sujetos y Resistencias - Debates y Críticas en Psicología Social. Santiago de Chile. Editorial ARCIS, 2002, p. 293-306.

HERNÁNDEZ, E. Participación: ámbitos, retos y perspectivas. CESAP: Caracas, 1997.

ICHIKAWA, E. Y.; SANTOS, L. W. dos. Contribuições da História Oral à pesquisa organizacional. In: GODOY, C. K et al. Pesquisa qualitativa em Estudos Organizacionais: paradigmas, estratégias e métodos. São Paulo: Saraiva, 2010.

LANE, S. T. M.; CODO, W (orgs.). Psicologia Social: o homem em movimento. 13 ed. São Paulo: Brasiliense, 1994.

MARTÍN-BARÓ, I. Psicología de la liberación. Madrid: Editorial Trotta, 1998.

MARTÍN-BARÓ, I. El latino indolente: carácter ideológico del fatalismo latinoamericano. In: MONTERO, M (coord.). Psicología política Latinoamericana. Caracas: Panapo, 1987, p.135-162.

MEDAETS, J. P.; FONSECA, M. F. de A. C. Produção orgânica: regulamentação nacional e internacional. Brasília: Ministério do Desenvolvimento Agrário: NEAD, 2005.

MELUCCI, A. Challenging codes. Cambridge: Cambridge University Press, 1996.

MINICUCCI, A. Dinâmicas de grupos: teorias e sistemas. Rio de Janeiro: Atlas, 2002.

MONTERO, M. Teoría y práctica de la psicología comunitaria: la tensión entre comunidad y sociedad. Buenos Aires: Paidós, 2008. 
MONTERO, M. Hacer para transformar: el método en la Psicología comunitaria. Buenos Aires: Paidós, 2006.

. Un paradigma para la psicología social: reflexiones desde el que haceren America Latina. In: MONTERO, M (org.). Construcción y Crítica de la Psicología Social. Barcelona: Editorial Anthropos, 1994.

MORO, D. A. Modernização da agricultura paranaense. In: VILLALOBOS, J. U (org.). Geografia social e agricultura. Maringá: PPG em Geografia-UEM, 2000. p. 27-60.

PERUZZO, C. M. K. Comunicação nos movimentos populares: a participação na construção da cidadania. Petrópolis, RJ: Vozes. 1998.

PORTELLI, A. História oral e poder. Mnemosine, v. 6, n. 2, 2010. Disponível em: http:// static.scielo.org/scielobooks/2k2mb/pdf/ferreira-9788575412879.pdf Acesso em: 14 de março de 2016.

ROCHA, M. L. da; AGUIAR, K. F. de. Pesquisa-intervenção e a produção de novas análises. Psicologia: ciência e profissão, v. 23, n. 4, 2003. p. 64-73.

SCARPARO, H.; GUARESCHI, N. Psicologia social comunitária e formação. Psicologia \& Sociedade, v. 19, n. 2, 2007. p. 100-108.

SÁNCHEZ, E. Todos con la esperanza: continuidad de la participación comunitária. AVEPSO XXIV, n. 2, 2000, p. 81-102.

SANDOVAL, S. A. M. O comportamento político como campo interdisciplinar do conhecimento. In: CAMINO, L.; LHULLIER, L.; SANDOVAL, S (orgs.). Estudos sobre comportamento político. Florianópolis (SC): Letras Contemporâneas, 1997.

. Algumas reflexões sobre cidadania e formação de consciência política no Brasil. In: SPINK, M. J. P (org.). A cidadania em construção: uma reflexão transdisciplinar. São Paulo: Cortez, 1994.

SEOANE, J (org.). Psicología Política de la sociedad contemporánea. Valência: Promolibro, 1990.

WACHOWICZ, R. C. Paraná, sudoeste: ocupação e colonização. Curitiba: Litero-Técnica, 1985.

WIESENFELD, E.; SÁNCHEZ, E. The why, what and how of community social psychology in Latin America. Applied Psychology, v. 40, 1991. p. 113-117.

Data de Submissão: 25/05/2017.

Data de Aprovação: 24/01/2018. 